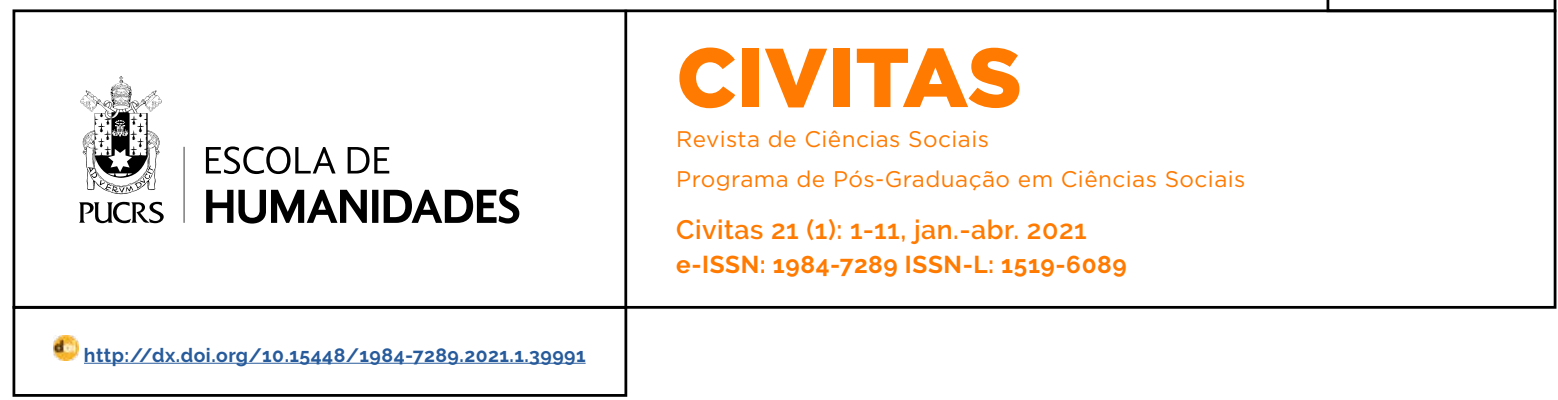

APRESENTAÇÃO/PRESENTATION

\title{
Teoria social e sociologia existencial
}

Social theory and existential sociology

Teoria social y sociología existencial

\section{Gabriel Peters ${ }^{1}$}

orcid.org/0000-0002-0595-2663

gabrielpeters@hotmail.com

\section{Diogo Silva Corrêa ${ }^{2}$}

orcid.org/0000-0001-5519-6985

dioscorrea@gmail.com

Miriam C. M. Rabelo3

orcid.org/0000-0002-5212-6129

mcmrabelo@uol.com.br
Recebido em: 22 jan. 2021. Aprovado em: 22 jan. 2021. Publicado em: 07 maio. 2021.
Resumo: Com base nos artigos que compõem o dossiê, os organizadores refletem sobre diferentes modos de conceber e levar a efeito uma sociologia existencial. Palavras-chave: Teoria social. Sociologia existencial.

Abstract: Based on the articles that make up the dossier, the organizers reflect on different ways of conceiving and carrying out an existential sociology.

Keywords: Social theory. Existential sociology.

Resumen: A partir de los artículos que componen el dossier, los organizadores reflexionan sobre diferentes formas de concebir y llevar a cabo una sociología existencial.

Palabras clave: Teoria social. Sociologia existencial.

Por que "sociologia existencial"? Como outras expressões nas ciências sociais, a noção nos parece suficientemente específica para designar o que singulariza certas perspectivas no polifônico universo da sociologia, de um lado, mas também suficientemente abrangente para abrigar uma variedade interna a essas perspectivas, de outro. Assim, para ficar somente em dois exemplos, consideramos a expressão pertinente para caracterizar tanto a reformulação crítico-sociológica de temas heideggerianos e sartrianos na fase tardia da obra de Bourdieu (2001; Peters 2012; 2017, 77-104), digamos, quanto tentativas recentes de interpretar sindromes psiquicas tais quais a depressão e o Burnout como sintomas históricos de uma "sociedade do cansaço" (Han 2015), cuja contraparte ideológica seria o "culto da performance" dos empreendedores de si (Ehrenberg 2010). Ademais, como sucede com a teoria social in genere, sempre parcialmente ocupada com a (re)definição do que ela própria faz e pretende fazer, o exercicio da reflexividade crítica pelos praticantes de uma "sociologia existencial" exige deles a disposição em redefinir os propósitos dessa área de reflexão e investigação em função dos resultados intelectuais que ela mesma gera. Tal dinâmica se refletiu, em 
certa medida, nas diferentes etapas de feitura desse dossiê, já que o projeto de uma "sociologia existencial" contido em sua proposta inicial teve de ser criticamente repensado, nessa introdução, com base nos artigos que compõem o dossiê na sua forma final, isto é, nos modos criativamente variados pelos quais suas autoras e autores levaram a efeito aquele projeto.

\section{Sociologia existencial e existencialismo sociológico}

Em A ordem social como problema psiquico (Peters 2017), um de nós desenvolveu o conceito de "existencialismo sociológico" como chave de interpretação de dimensões insuficientemente discutidas das obras de pensadores que, de resto, têm imensa influência na teoria social contemporânea, tais como Pierre Bourdieu, Anthony Giddens e Peter Berger (Peters 2012; 2014). Cada um à sua maneira, esses autores legaram à teoria social uma visão praxiológica segundo a qual a ordem societária não é meramente um dado, mas um contínuo resultado histórico das práticas de agentes interessados e hábeis. Longe de descambarem para o subjetivismo, cumpre ressalvar, os três também sublinharam que a dependência histórica das estruturas sociais em relação aos agentes humanos seria, por assim dizer, apenas um lado de uma mesma moeda ontológica, cuja face reversa seria a dependência desses agentes em relação àquelas estruturas. Se a continuidade histórica das estruturas depende da agência, disseram eles, as próprias motivações e competências que movem os atores humanos tampouco são dadas, mas derivam de sua socialização em cenários socioestruturais particulares. Ainda assim, a concepção radicalmente historicizada do mundo social veiculada por aqueles autores trouxe à baila uma inaudita dimensão "psíquica" ou "existencial" do que Parsons (1949, 89-94) e outros haviam antes chamado de "problema da ordem": se, como ensinam as praxiologias, a ordem social não é simplesmente dada, mas uma consequência contingente das práticas de agentes motivados e competentes, por que tais agentes investem tão continuamente, afinal de contas, na manutenção histórica dessa ordem? Ao denunciarem a "reificação" ou "naturalização" espúria do social em abordagens objetivistas, perspectivas praxiológicas agora tinham de explicar como a dependência contingente da ordem societária em relação às práticas dos atores humanos pode coexistir com a notável conjunção de força e durabilidade histórica dessa ordem, justamente os atributos que encorajaram observadores objetivistas a tratá-la (erroneamente) como uma realidade dada ou autossustentada. Trabalhando independentemente, Berger, Giddens e Bourdieu (sobretudo o Bourdieu tardio de Meditações Pascalianas 2001) desembocaram na conclusão convergente de que parte dessa explicação envolve capturar, no animal humano, um anseio existencial por uma experiência do mundo e de si próprio como realidades dotadas de ordem e sentido.

Não há espaço aqui para fundamentar tais afirmações com o necessário detalhe, já que isto demandaria o delicado inventário das semelhanças e dessemelhanças analíticas e terminológicas entre as obras dos três pensadores, para não falar no destrinchar das noções multidimensionais de "ordem" e "sentido", às quais seria decisivo acrescentar um conceito "sociológico-existencial" de "segurança ontológica" ampliado para além da sua acepção giddensiana (Giddens 2003, 444). Remetendo eventuais interessados ao livro em que essas tarefas são realizadas (Peters 2017), cumpre mencionar que a noção de "existencialismo sociológico" aflorou primeiramente para classificar quaisquer perspectivas que, como a trinca de autores elencados, postulava um vínculo entre a contingência da ordem social, de um lado, e o anelo existencial do ser humano por "segurança ontológica" (i.e., por um mundo vital imbuído de ordem e sentido), de outro. A aproximação entre os três autores implicou mostrar que Berger e Bourdieu operaram com um conceito lato de "segurança ontológica", ainda que, diferentemente de Giddens, não tenham mobilizado o termo propriamente dito em seus escritos.

Ainda mais importante, no entanto, foi a análise de como Berger e Bourdieu se avizinharam de 
um "existencialismo sociológico" não somente na conotação mais geral delineada acima, mas também no sentido mais especifico de que levaram a efeito apropriações críticas e reformulações sociológicas de motifs das filosofias "existencial" e "existencialista" tecidas por autores como Kierkegaard, Heidegger (pelo menos, o "jovem" Heidegger de Ser e tempo 2006) e Sartre. A tese heideggeriana de que o engajamento nas "ocupações" práticas oferecidas pela vida social cotidiana serve como uma espécie de escudo existencial protetor contra a consciência da própria finitude (Heidegger 2006, 328-329), por exemplo, ganha versões sociologicamente repaginadas tanto em Berger (1972, 164-165) quanto em Bourdieu (2001, 293) - conquanto o último seja muitíssimo mais crítico em relação às falácias "escolásticas" que animavam aquela tese na filosofia de Heidegger (Bourdieu 1983, 72; 2001, 293). Ao mirarem as implicações existenciais ou metafísicas do desempenho de papéis, identidades ou "missões" sociais, o sociólogo austriaco (Berger 1972, 102103; 158-162) e seu colega francês (Bourdieu 2001, 189) também se dedicaram a uma discussão crítica da psicologia sartriana da "má-fé" (Sartre 1997. 92-106) - uma vez mais, com críticas mais corrosivas fluindo da pena de Bourdieu contra seu compatriota filósofo. ${ }^{4}$

A profundidade com que sugestões de filósofos existencialistas informam os retratos bergerianos sobre o animal humano justifica qualificá-los sem embaraço, enfim, como uma forma de "existencialismo sociológico" (Peters 2017, 97-103). Por outro lado, a bateria de críticas pelas quais Bourdieu filtra motivos sartrianos e heideggerianos é de tal intensidade que parece menos uma indicação do quanto a sociologia pode aprender com o existencialismo do que, ao contrário, um argumento segundo o qual a sociologia (bourdieusiana, pelo menos) estaria intelectualmente mais bem equipada para res- ponder aos problemas da filosofia existencialista do que essa própria filosofia. Em outras palavras, Bourdieu ofereceria menos um "existencialismo sociológico", no qual a sociologia seria reformulada a partir das questões postas pelo existencialismo, do que uma "sociologia existencial", na qual as interrogações sugeridas pela filosofia existencialista é que seriam reformuladas e respondidas com instrumentos sociológicos capazes de superar suas limitações. Avaliar criticamente quão bem-sucedido Bourdieu foi nessa empreitada, sobretudo tal como ela floresceu nessa espécie de testamento intelectual chamado Meditações Pascalianas, é questão que escapa ao escopo dessa introdução. O que as considerações anteriores sugerem, entretanto, é a conclusão de que, ainda que todo existencialismo sociológico seja uma forma de sociologia existencial, nem toda sociologia existencial assume a forma de um existencialismo sociológico.

Se pensada nos marcos de um diálogo crítico e criativo entre a fenomenologia pós-husserliana, de um lado, e as ciências sociais, de outro, a sociologia existencial encontrará um nítido exemplar no primeiro artigo desse dossiê: "Fenomenologia e teoria social", de Paulo César Alves. Ao se debruçar sobre a sociologia fenomenológica de Alfred Schutz, Alves dá mais uma mostra de que, a despeito da alta circulação do nome de Schutz e do conceito fenomenológico de "mundo da vida" na teoria social contemporânea, o alcance, a sutileza e a complexidade das contribuições schützianas à reflexão socioteórica não obtiveram, ainda, o reconhecimento pleno que merecem. A influência do filósofo e sociólogo vienense sobre abordagens proeminentes - como a etnometodologia de Garfinkel, o estruturacionismo de Giddens ou a praxiologia de Bourdieu - é, decerto, comumente reconhecida. No entanto, tal reconhecimento costuma tomar a fenomenologia schutziana como uma teoria

\footnotetext{
4 Além de ser mais indulgente com as intuições de Sartre e Heidegger ao acomodá-las nas suas considerações sociológicas, Berger também se mostrou mais sensivel do que Bourdieu a temas kierkegaardianos, sobretudo quando ofereceu, com a ajuda de Arnold Gehlen, uma teoria "existencial" das instituições sociais (Berger 1972, 159; Berger e Luckmann 1985. 78; 80-81): na medida em que canalizam os potenciais de ação, pensamento e sentimento dos seres humanos para vias bem definidas (e.g., o casamento monogâmico no caso do desejo erótico-afetivo ou um idioma particular no caso da aptidão linguística), as instituições impedem que eles sejam assoberbados pelo que Kierkegaard $(2011,67)$, chamou de "vertigem da liberdade" aquele desorientador senso de possibilidades contingentes de vida que Berger $(1972,75)$ refraseou como "agorafobia metafísica".
} 
"idealista" da significação que serviria, na melhor das hipóteses, de preâmbulo àquelas "teorias da ação" de orientação praxiológica. Contra essa interpretação padrão, Alves sublinha que o primado ontológico da ação já se encontra desde o início na fenomenologia social de Schutz, cuja sofisticada análise da temporalidade também se entremeia a uma teoria da inter-relação entre esquemas significativos e práticas cotidianas em condições sociais plurais e incertas.

Apresentaremos os demais artigos do presente dossiê conforme avançarmos, nessa introdução, no exame de diferentes modos de compreender e desenvolver uma sociologia existencial.

\section{Sociologia existencial e antropologia filosófica}

No sentido mais básico, o rótulo de sociologia existencial se afigura colável em quaisquer perspectivas sociológicas dirigidas a inquietações que, tanto na terminologia acadêmica quanto no senso comum, são frequentemente descritas como "existenciais", as quais incluem os modos pelos quais os seres humanos imbuem sua existência de sentido e valor, enfrentam a consciência de sua própria finitude ou lidam com sua condição inerentemente dual de ser, a um só tempo, espírito e matéria - "metade anjo, metade besta" (Montaigne/Pascal), "sintese do físico e do espiritual" (Kierkegaard) ou, com ainda mais pathos, "um criador... que com imaginação pode...especular sobre o átomo e o infinito" sem deixar de ser, ao mesmo tempo, "um invólucro de carne...que irá definhar e morrer" (Becker 2010, 48). Tal concepção de sociologia existencial teria o mérito de libertá-la de quaisquer vínculos ortodoxos com o "existencialismo" como corrente filosófica específica, sem deixar de reconhecer, contudo, as contribuições decisivas legadas por membros dessa corrente para a compreensão da condição humana.
Como lembraram autores diversos, de Axel Honneth e Hans Joas (1988) até Charles Taylor (1988) e Frédéric Vandenberghe (2012, 11-37). qualquer reflexão teórica ou investigação empírica nas ciências sociais é obrigada a pressupor, mesmo que tão só implicitamente, alguma "antropologia" no sentido filosófico da expressão, i.e., uma concepção geral acerca do que significa ser humano. O reconhecimento dessa dimensão antropológico-filosófica nas ciências sociais leva rapidamente, assinalam tais autores, à consciência aguda de uma tensão entre a generalidade do humano, de um lado, e a variedade dos humanos, de outro. Por um lado, tanto a potência heurística quanto as implicações ético-políticas das ciências sociais derivam, em medida considerável, de sua insistência quanto à diversidade histórica e cultural das formas humanas de estar no mundo. A pars destruens desse esforço envolve, ademais, a crítica vigorosa a concepções do anthropos que simplesmente essencializam ou naturalizam, como traços universais do ser humano como tal, modos de agir, pensar e sentir que são característicos, a bem da verdade, de formações sócio-históricas específicas (tais como, digamos, a heteronormatividade, a religiosidade monoteísta ou a conduta econômica autointeressada). Por outro lado, o reconhecimento mesmo das múltiplas formas humanas de ação e experiência, propiciado, sobretudo, pelo alargamento das sensibilidades histórica e etnológica do saber sociocientífico, continua a pressupor alguma unidade na diversidade, isto é, o fato de que aquelas são formas de ação e experiência humana. ${ }^{5}$

Na medida em que os pressupostos mais gerais acerca da condição humana lidam necessariamente com temas caros à sociologia existencial, tais como as experiências de ser simultaneamente carne e espirito ou de ser obrigado a manejar a consciência da própria mortalidade, po-

\footnotetext{
5 As ilustrações desse ponto são abundantes: o exame de sistemas histórico-culturais diversos de classificação simbólica das entidades do mundo, por exemplo, no mesmo passo em que exibe sua exuberante variedade, também dá testemunho do status universal do ser humano como criatura classificadora ou "animal symbolicum"; a investigação do que é tido por "risivel" e "engraçado" em diferentes contextos sócio-históricos mostrará a extraordinária diversidade assumida pelo humor nas coletividades humanas, mas terminará por revelar o cômico e o riso como traços do humano como tal ("homo ridens"); a etnopsiquiatria e a antropologia cultural demonstrarão que formas de conduta consideradas perfeitamente normais em um cenário social serão rotuladas como "loucas" em outros e vice-versa, mas notarão também que alguma demarcação entre o "são" e o "insano" parece existir em todas as sociedades conhecidas; e assim por diante.
} 
der-se-ia dizer que toda perspectiva sociológica, ao pressupor uma concepção geral do "humano, seria em parte uma "sociologia existencial". Assim como as pressuposições antropológico-filosóficas sobre a conditio humana podem ser mais ou menos explicitas em diferentes abordagens nas ciências sociais, o mesmo aconteceria, pois, com suas diversas "sociologias existenciais" ou, dito de modo mais rigoroso, com a dimensão "existencial" de perspectivas sociocientíficas diversas. Tal dimensão poderia ser procurada em meio às figurações do humano que subjazem a tais perspectivas; portanto, através de tentativas de desencavar esses pressupostos antropológico-filosóficos nos trabalhos dos autores mais influentes nas ciências sociais: certa concepção do Homo faber, em Marx, como transmutação materialista do retrato hegeliano da autocriação humana na história; as diferentes versões de um Homo duplex atravessado por conflitos internos entre impulsos afetivos e controles morais em Durkheim ou Freud; o humano como criatura sedenta de sentido nos estudos histórico-sociológicos de Weber sobre as religiões mundiais ou nas suas reflexões tolstoianas em A ciência como vocação (1982, 166; 169-170), fundadas em uma antropologia filosófica que Raymond Aron (2000, 448) descreveu como um "existencialismo" avant la lettre; e assim por diante.

Embora tais leituras antropológico-filosóficas - ou "existenciais" em sentido lato - sejam mais frequentemente dirigidas à teoria social clássica do que a correntes contemporâneas, como os exemplos acima arrolados sugerem, interpretações que buscam as concepções do humano subjacentes às obras sociológicas de autores como Mead e Elias (Honneth e Joas 1988), Parsons e Habermas (Chernilo 2016) ou Schutz (Cefaï 1998) e Bourdieu (Pinto 2000, 144-163) nos parecem indicativas de todo um potencial programa de pesquisa exegética animado pela mesma intenção analítica. No seio desse programa de pesquisa, também poderiam caber reconstruções histórico-intelectuais de temas antropológico-filosóficos ou "existenciais" inescapáveis, tais como a corporeidade (e.g., as concepções de "corpo" na teoria social de Marx a Judith Butler, passando por Simone de Beauvoir e Foucault) e a finitude (e.g., as "tanatologias" explícitas ou implícitas na história da teoria social desde 0 suicidio, de Durkheim 2000 até, digamos, Necropolítica, de Achille Mbembe 2018). Os exemplos não são meramente acessórios, já que o projeto de uma sociologia existencial se entrecruza, em diversos aspectos, com uma "sociologia do corpo" e uma "sociologia da morte", tomadas não apenas como domínios de pesquisa empírica (e.g., sobre a variedade de representações culturais e experiências históricas da corporeidade e da mortalidade), mas também como elementos indispensáveis de quaisquer teorizações sobre a condição humana em sociedade.

\section{Sociologia existencial e a multidimensionalidade do ser no mundo humano}

Como dito antes, longe de querer enquadrar rigidamente as contribuições autorais a esse conjunto de artigos em uma concepção prévia de sociologia existencial, defendemos que os contornos desse âmbito de reflexão sejam repensados à luz da composição final do dossiê; portanto, a partir do que as autoras e autores que dele participam concebem como sociologia existencial nos seus artigos, seja de modo explícito e programático, seja de modo implícito e in actu. Dentre os sentidos de sociologia existencial que despontam nos textos do presente dossiê, um destaque pode ser concedido aos estudos que mobilizam a noção de "existencial" como índice analítico da multidimensionalidade do ser no mundo humano, i.e., do fato de que a existência humana no mundo engaja simultaneamente corporeidade e mentalidade, cognição e afetos, materialidade e simbolismo, individualidade e coletividade etc. Uma sensibilidade "existencial" na teoria social poderia ser identificada, assim, à intenção teórico-metodológica de tratar dessas dimensões da ação e da experiência humanas em termos de seus entrelaçamentos na realidade concreta, contra a comum "falácia da falsa concretude" (Whitehead 1925) que toma distin- 
ções analiticas entre aquelas instâncias como separações estanques vigentes no próprio real.

$O$ artigo de Paulo Alves que abre o presente dossiê já revela a conexão, estabelecida pela viagem transatlântica de Schutz e sua obra, entre correntes da filosofia e da ciência social europeia (e.g., Husserl, Bergson, Weber), de um lado, e os interlocutores filosóficos e cientifico-sociais que o autor vienense encontraria nos Estados Unidos, de outro. Schutz não só promoveu aproximações criticas entre sua fenomenologia social e abordagens estadunidenses nas ciências humanas (e.g., as versões de pragmatismo de James e Dewey), como terminaria produzindo um impacto significativo nas reações criticas ao estrutural-funcionalismo de Parsons que vieram a lume com força nos Estados Unidos a partir dos anos de 1960. 0 próprio Alves sublinha que, no bojo dessa inflexão na teoria social da segunda metade do século 20, autores como Jack Douglas (1972) e John M. Johnson (Douglas e Johnson 1977; Kotarba e Johnson 2002) propuseram explicitamente uma perspectiva analítica e uma agenda de pesquisa em "sociologia existencial".

Reagindo à ênfase excessiva dada por Parsons à internalização de "valores" e "normas" na personalidade dos agentes, a sociologia existencial dirigia três críticas ao paradigma parsoniano. Primeiramente, tal paradigma tomava o ator social como um receptor passivo de injunções sociais ou "idiota cultural" (na expressão contundente da etnometodologia de Garfinkel), minimizando a agência humana e a dimensão proativa dos indivíduos e das microssituações de ação na configuração e reconfiguração das estruturas sociais. Em segundo lugar, os defensores da sociologia existencial também acusavam os funcionalistas de serem excessivamente teóricos e abstratos, ignorando a experiência prática e concreta dos sujeitos no mundo. Os sociólogos de sensibilidade existencial asseveravam, pois, que a ação humana, baseada no "ser bruto" da existência, seria irredutivel ao que é imposto e requerido pela sociedade in toto, razão pela qual há sempre desvio, dissonância e conflito. Por fim, "sociólogos existenciais" como Douglas e Johnson sustentavam que a visão macrocentrada dos funcionalistas não só seria incapaz de atentar para os significados cotidianos que os individuos emprestam às suas ações mais prosaicas, mas também não dava conta de tudo aquilo que não fosse racionalmente inteligivel ou justificável em termos cognitivos e normativos ("accountable", na linguagem etnometodológica).

Por um lado, o programa de sociologia existencial de Douglas e Johnson convergia com outras abordagens interpretativas na critica ao excessivo "normativismo" de Parsons, o qual deixava de lado as competências cognitivas que os atores investem em suas ações e interações cotidianas. Por outro lado, aquele programa complementava essa critica com uma tentativa de escapar também ao perigo de um excessivo cognitivismo, buscando, então, se aproximar das formas pelas quais os atores não só veem o mundo, mas o sentem de uma maneira difusa que engaja o corpo e os afetos (Douglas 1977). Em uma visão mais ampla, complexa e multidimensional do humano como ser no mundo, a sociologia existencial se concentrava em uma dialética entre pensamento e sentimento que as pessoas experimentam juntas nas mais variadas circunstâncias da vida social ordinária. Desse modo, toda a existência social seria tratada como uma mistura prática de significados concretos e fugazes, significados que não são puramente cognitivos, mas, ao contrário, profundamente envolvidos e penetrados por sentimentos - por exemplo, definições de situação como "festa" e "funeral" não implicam somente um saber sobre como se portar em tais situações, mas um senso difuso das suas respectivas tonalidades afetivas. O cotidiano abordado pela sociologia não seria redutivel a uma soma de empreendimentos racionais, metódicos, intencionais e "accountable", mas comportaria uma contínua modulação de tonalidades afetivas que interferem decisivamente sobre os significados pelos quais o mundo social adquire sentido e inteligibilidade para os agentes.

Conquanto os artigos nesse dossiê não sejam retomadas ou desdobramentos ortodoxos da proposta de "sociologia existencial" de Douglas 
e Johnson, diversos textos aqui coligidos dão testemunho de uma relativa convergência de propósitos analíticos, sobretudo no compromisso com uma visão multidimensional do estar no mundo humano, visão que rejeita a ontologização espúria de distinções analíticas como aquelas entre cognição e afetos ou mente e corpo. Os artigos "A subjetividade corporificada nos marcos da sociologia existencial", de Lucas Faial Soneghet, e "Possiveis contribuições da fenomenologia e da etnometodologia para uma sociologia dos esportes coletivos", de Eduardo Nazareth, exemplificam tais retratos multidimensionais da subjetividade-no-mundo. Ambos reconhecem o caráter corpóreo dessa subjetividade sem recair, quer em um intelectualismo que toma o corpo como mero veículo passivo de intenções e capacidades mentais, quer em um comportamentalismo simplório que elide a inteligência criativa do corpo socializado ao reduzir as suas operações a associações mecânicas e fixas do tipo estímulo/ resposta. Entre os dois erros, certamente o mais comum na teoria social é a representação intelectualista do agente humano que reduz o corpo, na prática, a um objeto da consciência representacional ou a um condutor imediato de processos mentais. Não surpreende, assim, que diversas abordagens sociocientificas busquem recuperar o papel da corporeidade tanto como locus das intencionalidades e competências práticas do agente quanto como veículo da afetabilidade do mesmo agente pelo seu mundo vital. Dito de outro modo, com o suporte dos termos usados por Soneghet no segundo artigo desse dossiê, a subjetividade humana não somente "tem" um corpo; ela é subjetividade corporificada. Circulando com fluência no espaço hibrido em que as ciências sociais encontram a filosofia, Soneghet examina os retratos dessa subjetividade corporificada em autores como Merleau-Ponty, Goffman e Foucault.

O compromisso de uma abordagem existencial com uma perspectiva multidimensional sobre a ação humana também transparece, como dissemos, no texto de Nazareth sobre esportes coletivos, terceiro artigo desse dossiê. Graças ao impacto de autores como Norbert Elias e Pierre
Bourdieu, o esporte é hoje reconhecido não somente como uma área de pesquisa legítima em si, mas também como um viveiro de insights de aplicabilidade mais geral sobre a conduta humana em sociedade - no tocante aos modos de operação do habitus como "senso prático" no caso de Bourdieu, digamos, ou aos loci sociais de expressão "autorizada" da agressividade em sociedades marcadas pelo controle intenso de impulsos agressivos no caso de Elias. Se não surpreende que esses dois autores tenham tido um papel de proa na tentativa de trazer o corpo "de volta" à teoria social, o artigo de Nazareth inova ao aplicar um referencial analítico extraido de Schutz e Garfinkel ao exame sociológico de esportes coletivos.

Se os artigos de Soneghet e Nazareth são instâncias não apenas de uma sociologia do corpo, mas de uma teoria social que confere centralidade ao corpo, o mesmo pode ser dito, mutatis mutandis, quanto à temática da "morte" no artigo de João Lucas Tziminadis: "A domesticação técnica da morte: anti-aging como projeto existencial". Integrada a uma sociologia existencial, uma sociologia da morte pode se desenrolar não somente como um mapeamento dos atos, rituais, estratégias e representações variáveis pelos quais as sociedades humanas lidam com a morte e o morrer, mas também nas modalidades mais ambiciosas de uma sociologia "tanatológica", disposta a interpretar traços centrais da vida humana em sociedade, mesmo aqueles aparentemente desconectados com a mortalidade, a partir da condição incontornável da finitude (e da consciência dessa condição). Tratando de programas de prolongamento da vida como o anti-aging, culminação de uma longa trajetória histórica do que o autor chama de "conquistas tecnológicas sobre a morte", Tziminadis entrelaça ambas as sendas para uma teorização sociológica sobre a morte. Finalmente, como a ênfase sobre tecnologias de conquista da morte sugere, o autor também traz à baila uma tese que não pode ser esquecida nem por uma sociologia existencial nem por uma antropologia filosófica: a técnica não é mero acessório externo à condi- 
ção humana, mas um elemento constitutivo da humanitude da humanidade (i.e., do que faz dos humanos, humanos).

Os caminhos de uma sociologia existencial se encontram, em encruzilhadas diversas, com diferentes projetos intelectuais para uma "sociologia do individuo". Em seu artigo "Disposições, hábitos e provas: as sociologias do individuo de Bernard Lahire, Jean-Claude Kaufmann e Danilo Martuccelli", Rodrigo Vieira de Assis explora esse programa de teorização e pesquisa ainda em processo de feitura, porém já marcado por orientações analíticas heterogêneas. Como indica o título do artigo, o autor examina a teoria do ator plural de Lahire, a teoria dos hábitos de Kaufmann e a teoria da individuação de Martuccelli. No plano teórico-metodológico, um equilibrio heuristicamente instigante entre unidade e diversidade é propiciado pelo fato de que tais projetos para uma sociologia do indivíduo se desenvolvem contra o pano de fundo da teoria social francesa pós-bourdieusiana (Vandenberghe 2010, 85-110), presente na mistura que cada um deles encarna, ainda que em graus variados, entre traços "neobourdieusianos" (e.g., o vínculo sistemático entre teorização e empiria) e "antibourdieusianos" (e.g., a crítica às limitações da teoria do habitus). A sistematização teórica oferecida pelo artigo de Assis serve como um ótimo ponto de transição entre o bloco de textos formado pelos artigos de Soneghet, Nazareth e Tziminadis e a trinca subsequente que inclui os estudos de Peters, Grippaldi e Mocellim, nos quais a sociologia existencial veste a roupagem de uma sociologia histórica da psique contemporânea e seus dilemas.

\section{Sociologia existencial e sofrimento psíquico}

Utilizado para captar o enlace concreto entre as diversas dimensões da subjetividade humana engajada no mundo e por ele afetada, o adjetivo "existencial" também é comumente mobilizado, tanto no discurso acadêmico quanto no vocabulário de senso comum, como sinônimo de "psíquico". Tal uso do termo "existencial" continua a transmitir a ideia de vivências que engajam a subjetividade inteira do agente, entrelaçando indissoluvelmente a cognição e os afetos, processos mentais e corpóreos e assim por diante. No entanto, como sucede nas referências de senso comum a uma "crise existencial", esse núcleo de sentido pode se imbuir de uma referência mais específica aos dilemas envolvidos na tentativa de cada indivíduo em orientar-se em relação ao mundo. "Orientar-se em relação ao mundo" soa possivelmente como uma formulação demasiado vaga, mas o que há de vago nessa frase resulta, em parte, de uma exigência de realismo psicológico, i.e., do fato de que essa orientação (cognitiva e afetiva, "teórica" e prática, mental e corpórea; em suma, existencial) é uma vivência global e difusa intimamente conhecida de todo humano, porém dificil de capturar com nitidez na linguagem. O mesmo vale, ipso facto, para as caracterizações discursivas de avatares particulares dessa orientação existencial, como nas experiências de sentir-se à vontade e "em casa" no mundo (Gadamer 1996, 154) ou, ao contrário, de sentir-se condenado a observar a realidade a partir de fora (e.g., no caso de diversos quadros de depressão grave Ratcliffe 2015). Apaixonar-se, rir de algo que se achou engraçado ou sentir a passagem do tempo (para lembrar o exemplo agostiniano) constituem apenas três outras ilustrações dessas experiências que são, ao mesmo tempo, intuitivamente óbvias - já que vivenciadas no íntimo pela maior parte dos seres humanos - e terrivelmente enigmáticas - pelo menos quando buscamos exprimi-las com alguma nitidez na linguagem.

Seja como for, tal qual acontece nas referências do vocabulário leigo às "crises existenciais", parte dos esforços de uma sociologia existencial se dirige, então, a uma análise dos condicionantes sócio-históricos das gratificações e frustrações experimentadas pela psique individual em seu trato com o mundo. Para além de um discurso puramente teórico sobre as conexões entre felicidade/sofrimento psiquico e contextos sociais de vida, uma sociologia existencial também pode se debruçar, por óbvio, sobre instâncias históricas e culturais particulares de laço entre psique e sociedade. Passando de uma teoria social de 
alcance mais geral para uma teoria sociológica da contemporaneidade, os artigos de Peters, Grippaldi e Mocelim, nesse dossiê, exemplificam tal estilo de inquérito ao tratarem de fontes sistêmicas ou estruturais do transtorno depressivo e de outras modalidades de sofrimento psíquico características da modernidade tardia. Por um lado, os três textos atualizam a tese clássica de Mills segundo a qual a tarefa primordial da "imaginação sociológica" é a captação dos vínculos entre biografia e história, i.e., de laços entre microdilemas individuais e macroprocessos societários frequentemente insuspeitos aos próprios indivíduos neles embebidos. Por outro lado, ainda mais urgente para esses estudos parece ser o resgate de uma reflexão genuinamente sociológica sobre transtornos psíquicos como a depressão e o Burnout, frequentemente (mal) interpretados em termos hiperindividualizantes nos discursos da psiquiatria biomédica, da psicologia clínica, dos meios de comunicação de massa e, por intermédio dessas instâncias, dos próprios atores leigos em seus esforços por dar inteligibilidade e responder, na prática, ao sofrimento psíquico (próprio ou alheio). Longe de tencionarem substituir um imperialismo disciplinar por outro, através de uma simples rejeição da psiquiatria biomédica ou da psicologia clínica, os artigos de Peters, Grippaldi e Mocellim mostram o quão a individualidade biopsiquica é profundamente moldada por fatores sócio-históricos caracteristicos da modernidade tardia, tais como flexibilização do trabalho, aceleração da mudança tecnológica, inflação de diagnósticos psiquiátricos e modelos culturais da "boa vida" centrados no imperativo da atividade.

\section{Sociologia e existência}

A relação entre teoria social e sociologia existencial anunciada no título desse dossiê é, por certo, uma via heurística de mão dupla. Assim como insights oriundos da sociologia existencial podem ser transpostos ao coração da teoria social (e.g., a sugestão de que toda abordagem socioteórica possui uma "tanatologia", ainda que implicita), transformações na teoria social também provocam desdobramentos analíticos na arena sociológico-existencial. Pois bem: sob a influência de autores como Gabriel Tarde, Étienne Souriau, Gilles Deleuze, Bruno Latour, Isabelle Stengers e Tim Ingold, para citar apenas alguns dentre os mais vultosos, pressupostos clássicos da teoria social quanto às cisões entre natureza e cultura e entre humanos e não humanos foram severamente questionados. De um lado, a redução "humanista" da socialidade ao domínio das relações intersubjetivas entre seres humanos deu lugar a uma análise de associações em rede que coconstituem tanto humanos quanto não humanos. No mesmo passo que a agência ou "actância" de um conjunto heterogêneo de não humanos, como algoritmos digitais ou virus transmissores de COVID-19, foi integrada ao repertório ontológico de cientistas sociais, uma sensibilidade "associacionista" ou "associológica" passou a demandar, para muitos, uma reconceituação ontológica do natural e, de maneira mais radical, um senso ontológico pluralista de múltiplos modos de existência. Nesse sentido, repensada para além de seus sentidos antropocêntricos, o projeto de uma sociologia existencial se amplia em um repensar da problemática "sociologia e existência". A expressão é propensa a ganhar o prêmio epistemológico "Como recortar um objeto de pesquisa (só que não)", juntando-se a títulos hiperinclusivos como "Sobre o que existe" de William Van Orman Quine, O ser e o nada, de Jean-Paul Sartre, Totalidade e infinito de Emmanuel Lévinas e Ensaios sobre o que existe, o que não existe e outros assuntos (título para um livro nosso que não existe ainda). Não obstante, seria dificil encontrar um modo mais adequado de conceituar as implicações que as recentes "viradas ontológicas" nas ciências sociais acarretam para o projeto da sociologia existencial (Corrêa e Baltar 2020).

Como signo dessa conclusão que anuncia a passagem de uma sociologia existencial admitidamente antropocêntrica para uma que situa mais radicalmente os humanos nos seus modos de existência em rede com seres ontologicamente heterogêneos, o dossiê se encerra com o artigo de Miriam C. M. Rabelo e lara Maria de 
Almeida Souza: "Existências conjuntas e seus trajetos". A partir de seus respectivos domínios de investigação etnográfica na sociologia da ciência e na sociologia da religião, os ambientes ontologicamente diversos que coconstituem os sujeitos humanos de suas investigações comportam "animais outros que humanos" em um laboratório de pesquisa assim como "seres mais que humanos" nas práticas religiosas afro-brasileiras. Na esteira de autores como Tarde, Souriau, Deleuze e Latour, as duas pesquisadoras da UFBA encampam uma ontologia de modos plurais e dinâmicos de existência "enredada", perspectiva que implica não somente a mencionada reintrodução dos não humanos na análise sociológica, mas também a (igualmente mencionada) extensão do principio da socialidade ao conjunto dos seres existentes. Ao mobilizarem as reflexões de Souriau sobre modos de existência para tratarem do "existir-junto" naqueles contextos laboratorial e religioso, as autoras oferecem um exemplo de "filosofia empírica" no qual teorias com alto grau de abstração e realidades concretas do trabalho de campo se iluminam mutuamente.

Finalmente, o dossiê traz, além dos artigos, uma entrevista com um dos mais originais teóricos sociais críticos do presente, o sociólogo Hartmut Rosa, autor de uma teoria sociológica da aceleração na modernidade e de uma teoria social da ressonância como modo humano de relação com o mundo, duas densas perspectivas teóricas que contribuem para lançar luz sobre diversas temáticas relacionadas a uma sociologia existencial. Conduzida por Diogo Corrêa, Gabriel Peters e João Lucas Tziminadis, a entrevista explora os entrelaces da obra de Rosa com os temas do dossiê por vias variadas, as quais vão da interpretação da pandemia de Covid-19 em curso até as interfaces harmônicas ou conflitivas do pensamento do autor com figuras como Jürgen Habermas, Axel Honneth e Tristan Garcia.

A feitura desse dossiê, ainda mais nas condições biopolíticas trágicas que nos circundam, não teria sido possivel sem a colaboração competente, generosa e paciente de diversas pessoas. Competência, generosidade e paciência são adjetivos especialmente aplicáveis ao trabalho do editor André Ricardo Salata, de Maria Luísa C. E. Dios e dos demais membros da comissão editorial de Civitas, cuja participação em todas as etapas de construção deste dossiê - da aceitação da proposta até sua publicação - foi inestimável. Também agradecemos a todos os autores e autoras que enviaram seus artigos para essa iniciativa, assim como a todos/as que colaboraram com o processo como pareceristas. Unindo existências dispersas pela distância e pelo confinamento, os intercâmbios colaborativos que se materializam nesse dossiê dão testemunho de que a sociologia existencial é também um modo gratificante, em meio a tantas dificuldades, do "existir-junto".

Boa leitura!

\section{Referências}

Aron, Raymond. 2000. As etapas do pensamento sociológico. São Paulo: Martins Fontes.

Becker, Ernest. 2010. A negação da morte. São Paulo: Record.

Berger, Peter. 1972. Perspectivas sociológicas. Petrópolis: Vozes.

Berger, Peter e Thomas Luckmann. 1985. A construção social da realidade. Petrópolis: Vozes.

Bourdieu, Pierre. 2001. Meditações pascalianas. Rio de Janeiro: Bertrand Brasil.

Cefaï, Daniel. 1998. Phénoménologie et sciences sociales. Alfred Schutz: naissance d'une anthropologie philosophique. Paris: Librarie Droz.

Chernilo, Daniel. 2016. Debating humanity: towards a philosophical sociology. Cambridge: Cambridge University Press.

Corrêa, Diogo Silva e Paula Baltar. 2020. O antinarciso no século XXI. A questão ontológica na filosofia e na antropologia. Revista Critica de Ciências Sociais 123: 143-166. http://journals.openedition.org/rccs/11227

Douglas, Jack D. 1972. The experience of the absurd and the problem of social order. In Theoretical perspectives on deviance, organizado por Jack D. Douglas e Robert Scott, 189-214. New York: Basic Books.

Douglas, Jack D. e John Johnson, org. 1977. Existential sociology. New York: Cambridge University Press.

Durkheim, Émile. 2000. O suicidio. São Paulo: Martins Fontes.

Ehrenberg, Alain. 2010. O culto da performance. Aparecida: Ideias \& Letras. 
Gadamer, Hans-Georg. 1996. The enigma of health: the art of healing in a scientific age. Stanford: Stanford University Press.

Giddens, Anthony. 2003. A constituição da sociedade. São Paulo: Martins Fontes.

Han, Byung-Chun. 2015. Sociedade do cansaço. Petrópolis: Vozes.

Heidegger, Martin. 2006. Ser e tempo. Petrópolis: Vozes

Honneth, Axel e Hans Joas. 1988. Social action and human nature. Cambridge: Cambridge University Press.

Kierkegaard, Soren. 2011. O conceito de angústia. Petrópolis: Vozes.

Kotarba, Joseph A. e John M. Johnson. 2002. Postmodern existential sociology. Walnut Creek: Alta Mira.

Mbembe, Achille. 2018. Necropolitica. São Paulo: N - 1 edições.

Ortiz, Renato, org. 1983. Pierre Bourdieu - Sociologia Coleção grandes cientistas sociais. São Paulo: Atica.

Parsons, Talcott. 1949. The structure of social action: a study in social theory with special reference to a group of recent European writers. New York: Free Press.

Peters, Gabriel. 2012. O social entre o céu e o inferno: a antropologia filosófica de Pierre Bourdieu. Tempo Social 24(1): 229-261. https://doi.org/10.1590/S010320702012000100012

Peters, Gabriel. 2014. Ordem social e (in)segurança ontológica: esboços de existencialismo sociológico em Anthony Giddens, Peter Berger e Pierre Bourdieu. Politica \& Trabalho 40: 117-150. https://periodicos. ufpb.br/ojs2/index.php/politicaetrabalho/article/ view/20145/11166

Peters, Gabriel. 2017. A ordem social como problema psiquico: do existencialismo sociológico à epistemologia insana. São Paulo: Annablume.

Pinto, Louis. 2000. Pierre Bourdieu e a teoria do mundo social. São Paulo: FGV.

Sartre, Jean-Paul. 1997. O ser e o nada. Petrópolis: Vozes.

Ratcliffe, Matthew. 2015. Experiences of depression. Oxford: Oxford University Press.

Taylor, Charles. 1988. Foreword. In Social action and human nature, organizado por Axel Honneth e Hans Joas, vii-ix. Cambridge: Cambridge University Press.

Vandenberghe, Frédéric. 2010. Teoria social realista: um diálogo franco-britânico. Belo Horizonte: UFMG.

Vandenberghe, Frédéric. 2012. Uma história filosófica da sociologia alemã. Alienação e reificação. Marx, Simmel, Weber e Lukács, vol. 1. São Paulo: Annablume.

Whitehead, Alfred North. 1925. Science and the modern world. New York: Pelican Mentor.

\section{Gabriel Peters}

Doutor em Sociologia pelo Instituto de Estudos Sociais e Políticos da Universidade do Estado do Rio de Janeiro (lesp/Uerj), no Rio de Janeiro, RJ, Brasil; professor adjunto do Departamento de Sociologia na Universidade Federal de Pernambuco (UFPE), em Recife, PE, Brasil.

\section{Diogo Silva Corrêa}

Doutor em Sociologia pela École des Hautes Études en Sciences Sociales (EHESS) e pela Universidade do Estado do Rio de Janeiro (lesp/Uerj), Rio de Janeiro, RJ, Brasil; professor do programa de pós-graduação em Sociologia Política da Universidade de Vila Velha (UVV), em Vila Velha, ES, Brasil.

\section{Míriam C. M. Rabelo}

Doutora em Ciências Sociais pela Universidade de Liverpool, Inglaterra; Professora titular do Departamento de Sociologia e do Programa de Pós-Graduação em Ciências Sociais da Universidade Federal da Bahia (Ufba), em Salvador, BA, Brasil. 